\title{
ENGLISH SKILLS FOR STAFF OFFICERS: COLLABORATIVE DEVELOPMENT OF THE DISTANCE COURSE
}

\author{
Olga DANYLOVA, Peggy GARZA, Bonnie MIHALKA, \\ Kateryna SYNYTSYA, and Olexiy VOYCHENKO
}

\section{Introduction}

With the advent of the NATO Partnership for Peace (PfP) program, English has become increasingly important as the operational language for multinational activities. One common language, English, is essential for interoperability within NATO/PfP. As multinational activities with the new Partner nations began, a language problem came to light. Not all the key military personnel participating in these activities had the necessary language skills to function effectively and this, in turn, had a negative impact on the success of NATO/PfP operations. Also troubling was the observation that some staff officers working in NATO headquarters lacked the language skills to perform independently in their assigned tasks, without the assistance of a native English-speaking colleague. A significant part of the "language problem" was determined to be a deficiency in "operational" English, or the language skills and vocabulary required for a specific purpose, such as multinational operations or staff work. This, in turn, had a negative impact on the success of NATO/PfP operations.

In 1996, representatives from the Defense Language Institute English Language Center (DLIELC) conducted a detailed needs analysis in close cooperation with the NATO School in Oberammergau, Germany, and the Partnership for Peace Coordination Cell in Mons, Belguim. This analysis showed that the language skills required for military professionals in NATO/PfP contexts included memo and report writing, group discussion, and oral presentations or briefings. Also important was the terminology commonly associated with the topics of NATO, NATO Standardization Agreements (STANAG), peace support operations, and interoperability. In response to the needs analysis findings, the DLIELC then developed the English Skills for 
Staff Officers (ESSO) course to address this operational language gap for the target audience of professional military personnel functioning in a multinational NATO environment.

The ESSO course is aimed at individuals who already have a high intermediate or advanced level of proficiency in English. It is not a basic course in English; rather it is intended to polish or refine an already existing knowledge of English while simultaneously providing practice in the specific language skills required in a professional multinational military context. The original course was paper-based with supporting audio cassettes. The student package included a paper textbook, a paper dictionary and several audio cassettes. Answers to the activities were provided for self-correction. Student packages had to be mailed to students enrolled in the course.

Growing participation in multinational operations and the extent of international collaboration in security issues was a driving force in the search for advanced ways of delivering content and supporting self-study. Thus, distance learning technologies that had already proven to be effective for distributed audiences, adult training and retraining and individual learning support came into focus. ${ }^{1}$

A survey conducted by the Working Group on Individual Training and Education Developments of NATO's Joint Services Subgroup identified English and NATO terminology as critical content areas for on-line distance learning. Thus the on-line ESSO course focusing on English language proficiency and acquisition of NATO terminology was created. The purpose of the on-line course is to engage officers in language learning and to facilitate the language learning process by the use of modern technologies. The course is primarily intended for self-study and may be followed or accompanied by instructor-led activities either in a classroom or on-line. It is expected that the course will be used by officers to prepare for their classroom training sessions, as an instrument for helping to keep language skills current, or as a reference book containing templates, examples and guidelines for applying their writing and speaking skills.

\section{Planning}

Language learning is one of the areas where distance courses are successfully offered both in a self-study and instructor-led mode. ${ }^{2}$ Computer-based learning may facilitate language learning by supporting traditional exercises, adding automatic feedback, providing supplementary materials, enhancing visualization, and extending activities performed in language learning. A number of approaches were studied and tested, covering a range from small, narrowly focused projects (enhancing vocabulary, mastering a specific grammar topic, etc.) to elaborate learning environments based on advanced technologies (speech recognition, in-depth text analysis, video-materials, 
annotation, etc.) The results bear witness to the fact that the success of the project depends on understanding the needs of the audience and their restricted technical capacities as well as clearly stated goals, rather than on scale or technical advancements.

Another factor important for successful accomplishment of the project is effective communication among the members of the development team. Multimedia distance courses are usually implemented by a group of professionals representing different areas of expertise, including subject matter, instructional design, multimedia design, human-computer interaction, and programming. Although a significant part of the ESSO content development has been already done, a close cooperation among the language course instructors and distance course designers was necessary to set up priorities and evaluate proposed design decisions.

All team members should understand the goal, requirements and framework within which they may employ their creativity and expertise. In an international team, different native languages add complexity to the communication among experts who tend to use their respective professional languages and terminology. Although most of the communication on ESSO was done by email, a couple of short meetings were essential in establishing a common framework of understanding and clarifying issues that were difficult to verbalize.

The initial needs analysis gave birth to a modular, paper-based ESSO course based on rich learning content, diverse exercises, and extensive self-assessments. It was a good starting point to explore a potential of multimedia and information technologies to support the entire spectrum of language learning activities, including reading, writing, listening, and speaking.

The course is intended for an international audience, which should be able to access it from different locations using various computer platforms. As there was no detailed information on software or bandwidth of the channels, the developers aimed at the Internet browsers, Netscape Navigator starting from version 4.73, and MS Explorer 5.0 and higher. This corresponds to the low end of personal computer configurations and is consistent with the requirements of the Partnership for Peace Learning Management System (PfP LMS) - a free software tool widely used by the members of the PfP Consortium. ${ }^{3}$ Interactive multimedia courses usually place a higher demand on the quality of the Internet connection. Based on a survey of the Internet infrastructure in CIS ${ }^{4}$ countries, the target was set up at a dial up access with 33.6 modem (average speed $4 \mathrm{~K}$ per second), and a download time of at most 2 minutes for large audio files. Supportive multimedia are displayed at the same speed as the main body of the lesson. 
Another decision made by the team was on the use of special software to vary learning activities and make feedback to the user more intelligent. There are a number of related issues:

- Availability of free software for users' platforms;

- Administrative policy on installation of new software (when using a course from a public or office computer);

- Complexity of software installation;

- Availability of user's manuals corresponding to the computer literacy level of ESSO users.

Thus, at the first stage no additional software (such as speech recognition or audio speed regulation tools) was recommended for ESSO. However, some provisions were made to make multimedia fragments designed in Macromedia Flash 5.0 available for users without respective plug-ins by storing alternative formats (gifs and java-script based).

To simplify course maintenance and further updates, the course was developed using the authoring tools of the PfP LMS. ${ }^{5}$ As with any tool, this puts certain limitations on the course presentation and features, but the benefits of a systematic tool-based approach were expected to be significant in the long run.

\section{Instructional Design Issues}

On-line delivery cuts the expense of reproducing and mailing student packages but increases the burden on the student's side. Internet access is still expensive in many countries, whether it is paid by an organization or the student, it is still not as common as the TV or VCR, and requires certain skills to operate efficiently. The key question to be answered by the developers was: "What features of the distance course will justify the on-line delivery of ESSO?".

To answer this question, the team studied a variety of language courses on the web, compared them to other on-line courses, identified typical learning activities and mapped them to the learning objectives of the original ESSO course. Although most contemporary distance courses are oriented to support learning activities, one can still find presentation-based courses, especially those that are intended for familiarization with or factual understanding of a subject. Language courses are primarily focused on the development of skills, whereas acquisition of knowledge and attitudes is considered rather as a basis for skills acquisition. ESSO represents both of these content areas, skills acquisition and subject matter instruction, together in one course. Thus, it is essential to sequence activity-based learning and create a learning environment with timely and focused feedback and performance-based assessments. ${ }^{6}$ 
It is also important to establish a communication medium, as communication in a foreign language is a goal for students of ESSO, as well as a tool for knowledge and skills acquisition. Finally, it is desirable to provide a spectrum of tasks and exercises for reinforcement of the acquired skills and additional activities that may be helpful to keep skills current. For example, since one of the purposes of ESSO is to develop professional communication skills, the guidelines and templates for taking notes, preparing a briefing, summarizing, etc., should be available for further reference.

In the ESSO course, one can distinguish typical language learning activities (vocabulary development, grammar rules mastery, understanding speech and text fragments, etc.) and professional language activities (preparing documents of a certain type, developing presentation skills, etc.).

In both cases, there is a significant amount of material to be internalized. ${ }^{7}$ To facilitate learning and retention, instructional designers should create some motivation to keep the learner's senses active and provide the same information in multiple ways, so that it is perceived through several channels. This will also address diversity in learning styles and support learners who have strong preferences with regard to the way information is presented (text vs. audio, visual structures vs. text, etc.). Another way to make self-learning more effective is to properly structure learning material and select the appropriate presentation for each fragment depending on its purpose. Important information should be clearly identified and supplementary material should be separated and presented rather on-demand to keep the learner focused.

Critical success factors for self-learning include supplying the learner with the necessary information for learning control, providing timely feedback, hints and help, informing him/her about strategies that may make learning more effective, supporting navigation, and ensuring clarity of the learning objectives. It is essential that the environment be arranged in a way to facilitate focusing on learning activities by establishing an authentic context and eliminating uncertainties. Learning activities should vary to capture interest and challenge the learner; they should allow for mastering skills at one's own pace and provide opportunities for practicing and gaining experience.

To summarize the desired features of the on-line implementation of ESSO, a brief comparison is given in Table 1.

In subsequent sections we will give some examples of ESSO's on-line implementtation to illustrate our approach. 
Table 1. Comparison between the original and the on-line ESSO course

\begin{tabular}{|l|l|l|}
\hline Feature & Original ESSO & On-line implementation \\
\hline $\begin{array}{l}\text { Presentation } \\
\text { media }\end{array}$ & $\begin{array}{l}\text { Text, illustrations, } \\
\text { audio }\end{array}$ & $\begin{array}{l}\text { Enhanced by animation, video } \\
\text { fragments, and interactive multimedia }\end{array}$ \\
\hline $\begin{array}{l}\text { Information } \\
\text { arrangement }\end{array}$ & $\begin{array}{l}\text { Structured by units and } \\
\text { activities; answers and } \\
\text { supplementary } \\
\text { information provided in } \\
\text { the annexes }\end{array}$ & $\begin{array}{l}\text { Enhanced by availability of } \\
\text { supplementary information in separate } \\
\text { windows, visual indication of learning } \\
\text { content type, provision of additional } \\
\text { on-line sources }\end{array}$ \\
\hline Motivation & $\begin{array}{l}\text { Supported by learning } \\
\text { objectives, content, and } \\
\text { exercises. }\end{array}$ & $\begin{array}{l}\text { Enhanced by variety in presentation } \\
\text { and activities, interactive feedback, live } \\
\text { language sources available on-line }\end{array}$ \\
\hline $\begin{array}{l}\text { Learning } \\
\text { activities }\end{array}$ & $\begin{array}{l}\text { Typical for self-study, } \\
\text { some answers and hints } \\
\text { are provided }\end{array}$ & $\begin{array}{l}\text { Several types of exercises are offered } \\
\text { on-line with interactive feedback }\end{array}$ \\
\hline
\end{tabular}

\section{Information arrangement and presentation}

Although skills acquisition is mostly based on the learner's activities, an enhanced presentation of the course also plays an important role in facilitating understanding and retention, and making learning more efficient. Due to certain limitations in layout and extensive multimedia use, the designers focused on structuring the information in an appealing way, presenting it in a variety of ways, and separating information to be learned from supplementary information and instructor's guidelines. In the on-line ESSO implementation, the following issues were addressed:

- Grammar. Static and animated pictures are especially useful to illustrate grammatical constructions and transformations (passive to active voice, direct to indirect question, etc.);

- Objective vocabulary. New vocabulary words, which are highlighted at their first occurrence in the text, are linked to the respective vocabulary information including spelling and audio (see Figure 1). Vocabulary for each unit is also available from the supplementary lessons containing handout information;

- Military acronyms and abbreviations. Every unit contains 15-20 NATO acronyms and abbreviations that should be remembered. Some of them are formed from the first letters of the constituent words and are relatively easy; 
others may contain several letters from a particular word or words. The construction of the latter is illustrated by animation;

- Large text readings may be downloaded as PDF files to be available offline for further references. Supplementary information normally given in annexes is available for download but may also be opened as a guide in a separate window. Thus a learner may collect all necessary sources and tools at his/her virtual desk, creating a personal environment for language learning.

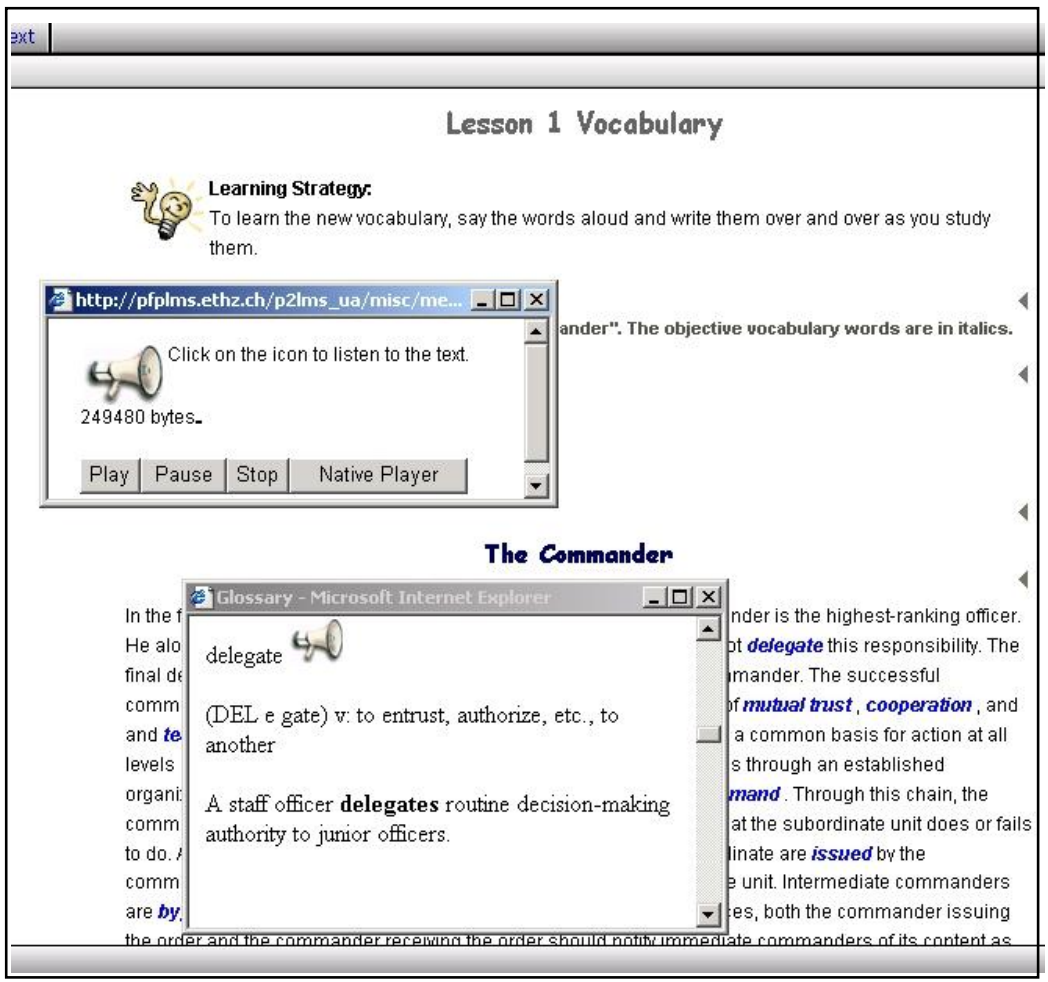

Figure 1: Implementing Objective Vocabulary.

\section{Motivational support}

There is a high probability that the main reason the early application of computers in education showed good results is that it was something new and exciting. Computers and IT in general are not a novelty anymore; moreover, there are certain expectations about the look and feel of the computer-based materials that are often inspired by 
entertainment, games, and news sites. Although the potential users of the ESSO course are no doubt highly motivated, the developers decided to add some minor details that may make language learning more exciting, such as on-line crosswords or funny animations. Some animated explanations are not only functional but also humorous and relaxing, which may serve to move some of the conscious learning efforts to the unconscious level (Figure 2).

\section{Lesson 15 Troublesome Grammar}

\section{Fanther vs. Further}

Although it is not uncommon to hear these words used interchangeably, it is important to point out that farther is used to denote comparative distance, whereas further denotes comparative degree or extent.

Examples:

The amphibious vehicle was driven farther into the water.
The commander ordered the troops to move five kilometers farther
down the road
down the road.

We will look into the matter further. Thttp://pfplms.ethz.ch/p2lms_ua/objects/395.. $-\mid[a|x|$

We will inform you of further developments FARTHER

Click on the animation icon to see Farther ,

\section{Exereise}

Figure 2: Motivational support.

For those who wish to enrich their language beyond the course requirements, a number of Internet links are offered, including news sites and NATO's site, which includes a large multimedia library. The variety of materials offered in English there, including publications, speeches, video records and current news allows the student to find both interesting and professionally beneficial content. Thus professional 
motivation is enhanced by natural curiosity, and the learning experience is extended by authentic multimedia.

\section{Exercises and activities}

There are three types of learning activities offered in the on-line ESSO course. The first type comprises multiple-choice tests and other exercises where a correct result is specified and assessment of the learner's answer is done automatically. In the second type of activity, answers may vary significantly, so their complete assessment may be reliably done by a human only, however some correct sample answers are offered to the learner for comparison purposes. The third group of exercises is intended solely for human evaluation.

Some examples of the first type include automatically assessed exercises, typical multiple-choice questions with or without a menu, fill in the blank, selection of certain parts of the sentence, and ordering. For the types of exercises that require user input rather than the selection of the correct answer, the program is capable of recognizing more than one correct answer, and the answer may be either typed or copied from the text on which the exercise is based.

Answers to the second type of exercise may be typed either in an input field and compared with a sample answer given under this field upon request or entered as a Note to the course. The student uses the Note function to record an observation, summary or an overview, either on his own initiative or when prompted to do so in response to a request. This written material may easily be copied to a local file for future reference. Sample answers for this case, by contrast, are demonstrated in a separate window to facilitate comparison with the answer proposed by the learner.

The third type of exercise currently does not require any input into the system, since the student's local environment may provide more services for language learning. For instance, one can use a built-in spell-checker or locally installed dictionaries, a presentation may be created in MS PowerPoint, or some text-to-speech or dictation software used to evaluate the results. For the instructor-led mode, the course will offer individual and group activities that may be evaluated by the instructor. An example of individual learning is a dialogue exercise. The dialogue is presented to a student both by audio and written text as a whole, then he/she may select a role and a speed at which his/her part of the dialogue will be spoken (Figure 3). There is an indication of the remaining time, and the student's text is displayed as in karaoke. This activity may be further elaborated by use of sound-recording software and comparison of the student's speech with a sample audio. This feature however may require additional software installation on the students' computers. 
Now, practice the dialogue. If you have a Flash Player on your computer, you can practice any role at different speed. Otherwise, click on the Sound icon. You will hear Jeff' part of the conversation. Read Lt Lee 'part.

Click on the icon to load the interactive dialogue.

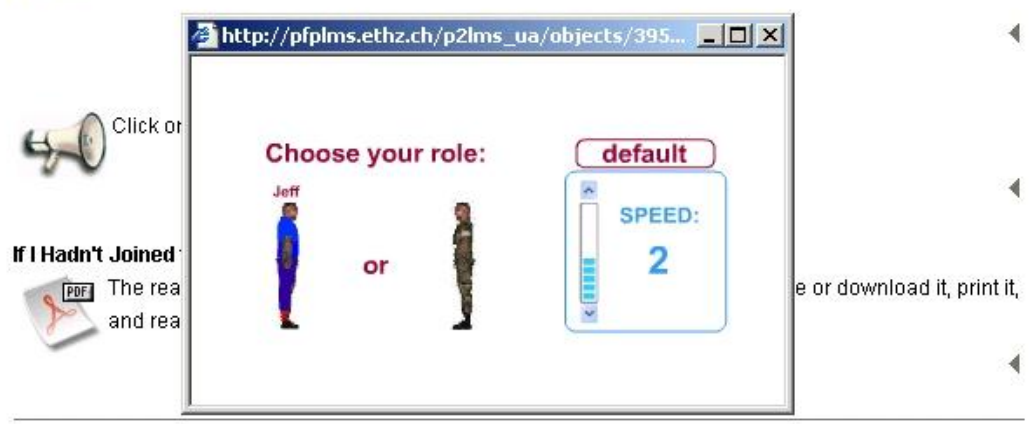

Figure 3: Interactive dialogue exercise.

\section{Pilot Testing}

The George C. Marshall European Center for Security Studies offers programs focused on the democratic transition and international security to government officials from over forty countries at its site in Garmisch-Partenkirchen, Germany. Forty-five Marshall Center course participants were asked to test pilot ESSO and provide feedback on its design and content as part of their English as a Foreign Language (EFL) classes at the Marshall Center. All forty-five were high intermediate or advanced students of English.

The participants spent one or more hours working through the units which comprise ESSO with prior guidance from their language instructor. Some twenty test piloted ESSO on their computers in private and reported back to the instructor, while the remainder worked through the course units in a computer language lab with the instructor present. The quality of the feedback varied somewhat depending on the linguistic and technical sophistication of the individual participants. Specific feedback was solicited about the potential benefits and problems of accessing and working with ESSO in their home countries.

Overall, the participants were very enthusiastic about the course. Each of them wanted assurances that ESSO would be available on-line in the future and they would have access to it from their home countries. In particular, they responded positively to 
the multimedia features, including animation and opportunities for role-play. Certain design elements were cited as quite useful. For example, ESSO offers several options for finding definitions to unknown words quickly, obviating the distraction of looking up new words in a paper-based dictionary. The audio function allows participants to hear and read certain texts simultaneously, certainly a helpful feature in learning English, in which the spoken and written word can be so dissimilar. Finally, the use of targeted content, e.g., information staff officers need to know about NATO and multinational operations, as a basis for focused language-learning makes the effort of working through the course seem worthy of the participant's time and effort.

Participants were eager, but uncertain, about continuing to work with ESSO from their home countries. Thus the developers had to postpone implementation of bandwidth-critical features of the course, such as video, as even some audio materials were slow to load and participants assumed such features would tax the capabilities of their computers at home. Those participants with lower levels of computer literacy had less confidence in their ability to work through ESSO on their own, without access to expert advice.

The process of getting started in ESSO and proceeding through the units is selfevident. While feedback from the test piloting was used to correct errors, clarify instructions to exercises and make changes to help facilitate working through the course material independently, there is still a need for an instructor to be on call to help explain, direct and support the participant. At certain points, for example, ESSO prompts participants to produce written text, which cannot be adequately evaluated except by an instructor. Other exercises suggest that the participant have a partner to communicate with. Technical problems with the computer may also make access to expert advice an important element in completing ESSO successfully.

\section{Conclusion}

The feedback obtained during pilot testing has reinforced the decisions on future enhancements of ESSO. Students shared some doubts related to the capacity of the environment back in their home countries to be appropriate for download and storage of large files. In addition, there is the issue of Internet traffic fees, especially when using streaming media that cannot be saved locally, and of the performance of additional software, such as audio players, which varies from one system to another. Observing students' behaviors, we found that they may benefit from some knowledge of the technical side of distance learning, which could help them manipulate the system in case of transmission delays and other undesirable situations. Therefore, future versions of ESSO may include both an enhanced introductory section of the course and context-related help. 
One of the stated benefits of distance courses is their potential to stay current by being updated on a regular basis. This is especially important for ESSO, which is based on current NATO and PfP materials and presents not only a lexical part but also a current vision of multinational collaboration. A framework for consistent updates will be based on a SCORM approach to learning content aggregation, sharing and reuse. Both the significant amount of multimedia content that may be reused and the need for continuous updates suggest the benefits of sophisticated content authoring and management.

Future plans include provisions for a CD-ROM version of the course for individual use to save on Internet fees. For those who would like to benefit from communication with an instructor and classmates, a number of classroom activities will be prepared. The students expressed interest in being exposed to authentic multimedia, though at the same time they recognized the usefulness of a tutor's explanations and guidance. These needs for instructor-mediated authentic multimedia-news, sample presentations, reports, and dialogues - may be addressed by creating a collection of respective materials that will be accessible within the course.

During the enhancement of the course, the developers plan to continue pilots and monitoring of students' needs, including infrastructure development in their countries. This would allow the developers to focus on the current priorities and at the same time plan for long-term use of the course.

ACKNOWLEDGEMENTS. We would like to thank our colleagues, namely, Ms. Martha Lopez-Durkin and Ms. Gracie Funk (DLIELC), Swiss CDT, Mr. Sergey Sevastyanov, Mr. Andrey Podgognov, and Mr. Dmitry Rovinsky for their creative participation in the project and professional contributions to its results including those reported in this paper. We would also like to thank ETHZ for sponsoring the project, the PfP Consortium and, personally, Cpt. Thomas Schneider (GCMC) for administrative support.

\section{Notes:}

1 Susan Schor Ko and Steve Rossen, Teaching Online: A Practical Guide (Boston, MA: Houghton Mifflin Company, 2002); Curtis J. Bonk and Robert A. Wisher, Applying Collaborative and e-Learning Tools to Military Distance Learning: A Research Framework, Interim Technical Report (Alexandria, VA: US Army Research Institute for the Behavioral and Social Sciences, September 2000), <http://www.publicationshare. com/docs/Dist.Learn(Wisher).pdf> (5 May 2004); Allan H. Schulman and Randi L. Sims, "Learning in an Online Format versus an In-class Format: An Experimental Study," T.H.E. Journal 26, 11 (June 1999), <http://www.thejournal.com/magazine/ vault/A2090.cfm> (5 May 2004). 
2 Yong Zhao, The e-Language Learning Project: Conceptualizing a Web-based Language Learning System, A White Paper (East Lansing, MI: College of Education, Michigan State University, September 2002), <http://ott.educ.msu.edu/elanguage/about/ whitepaper1.pdf> (5 May 2004).

3 www.pfpconsortium.org

4 CIS - Commonwealth of the Independent States.

5 http://pfplms.ethz.ch/p2lms_ua/pfplms.html

6 Judith Gordon, "Designing a Distance Education Program for English for Special Purposes (ESP)," TESOL Matters 9, 2 (April/May 1999), <http://www.tesol.org/isaffil/ intsec/columns/199904-esp.html> (5 May 2004); Carol A. Chapelle, "Multimedia CALL: Lessons To Be Learned From Research On Instructed SLA," Language Learning and Technology 2, 1 (July 1998): 22-34, <http://lt.msu.edu/vol2num1/article1/index.html> (5 May 2004); Marta González-Lloret, "Designing Task-Based Call to Promote Interaction: En Busca de Esmeraldas," Language Learning and Technology 7, 1 (January 2003): 86-104, <http://lit.msu.edu/vol7num1/pdf/gonzalez.pdf> (4 May 2004).

7 Peter J.M. Groot, "Computer Assisted Second Language Vocabulary Acquisition," Language Learning and Technology 4, 1 (May 2000): 60-81, <http://llt.msu.edu/ vol4num1/groot/default.html> (4 May 2004).

PEGGY GARZA, MBA, M.A., Teaching English as a Second Language, is the Chair of the English and German Department of the George C. Marshall European Center for Security Studies in Garmisch-Partenkirchen, Germany. She has extensive experience in curriculum development and testing and has given numerous presentations on those subjects. She is also the Secretary for the Bureau for International Language Co-ordination, an advisory body to NATO on language teaching matters. For correspondence: The George C. Marshall European Center for Security Studies, Gernacker Strasse 2, Garmisch-Partenkirchen D-82467, Germany; phone: + 498821750 792, fax: + 498821750 896. E-mail: garzap@ marshallcenter.org.

BONNIE MIHALKA, MA, MBA, is an instructor for English and German at the George C. Marshall European Center for Security Studies. Her professional interests include second language lexical acquisition, language skills acquisition through distance learning and media relations training. E-mail: mihalkab@marshallcenter.org.

OLGA DANYLOVA and ALEX VOYCHENKO are junior researchers at the International Research and Training Center (IRTC) for Information Technologies and Systems. They got their M.Sc. in intelligent decision-making systems, and are members of the Ukrainian CDT at the PfP Consortium. Olga is finishing her PhD work. Her research interests are focused on instructional design, content management, heterogeneous adaptive educational systems, and multimedia for instructional design. Alex is doing research in m-learning, personalization issues and learning resource collections. They participated in a number of distance courses development projects, a school learning portal development, and multimedia applications design.E-mails: danilowa@rambler.ru; asher_alex@hotmail.com.

KATERYNA SYNYTSYA, PhD, is a senior researcher at the International Research and Training Center (IRTC) for Information Technologies and Systems and a leader of the Ukrainian Cooperative Development Team. Her research interests are mostly related to elearning, including knowledge management, metadata for learning resources, adaptive systems, life-long learning and IT standards for education. For correspondence: IRTC, pr. Glushkova, 40, 03187 Kyiv, Ukraine.E-mail: kath@umod.kiev.ua. 